A. N. BOSE

\title{
EVOLUTION OF CIVIL SOCIETY AND CASTE SYSTEM IN INDIA
}

THE TRIBAL HERD

In some passages of the Rgveda ${ }^{1}$, the Upaniṣads, the Mahābhārata and the Pali canon there are references to a casteless millennium of equality, plenty and piety which was supposed to have existed in some remote unrecorded antiquity. It was the golden age of krta ${ }^{2}$ or satyayuga when there was only one caste of deva (gods) or Brāhmana, when people called no goods their own nor women their chattels, when crops were produced without toll and all were pious and happy. The legendary Uttarakurus of the far north were a model of this Arcadian society of godly men who lived in their natural virtue, rich in physical and moral wealth without any disabilities of sex and distinctions of property and, consequently, who received the blessings of God in the form of timely rain and juicy harvest (Mbh. VI. 6. 13; Dïghanikāya, xxxii. 7).

This tradition of the kyta age to which ancient literature hark back again and again was undoubtedly a myth. Poets and idealists who were oppressed by the social disparity, scarcity and unrighteousness of their days, nursed a utopia of peace, plenty and piety, made this vision a dead reality of the past and called for its revival. It was a myth made for the sustenance of failing hope. But the myth had a kernel of fact which was thickly overlaid with fancy. It conceals the vague outline of a society which glimmers in the twilight of prehistory.

The first page of the history of man is written with stone. He had burst into a new horizon from the darkness of animality. But the instinct of the herd was still in him. Like animals he roamed about in herds armed with the implement of stone, the first invention of science. The

1 See Sources, p. I 21 .

2 See Glossary of Sanskrit Words, p. ז 20. 
strength of collective living and the dawning mind of science, - these were his only resources against the hostile forces of nature. The second scientific invention of the tribal herd was fire, the means to combat cold, enemy and forest. The men roasted the meat of game, warded off winter and wild beasts and cleared the forest for their habitat.

At this stage breaks the twilight of prehistory in India. The woods and the caves were lighted by the leaping flames of the altar. The frail biped faced the furies of nature. He discovered the two primal gods, Sun above and Fire below, reservoirs of elemental energy wherefrom life draws its vitality. The skies rang with the hymn of aditya (sun) and agni (fire). The gods were besought for victory, wealth, pleasure and strength. The mystic lores of gäyatri and pañchägni were physical and psychic exercises for assimilation of solar and fire energy. And energy is the source of riches and joy. "Oh fire! Thou knowest all the activities of the earth. Take us along the blessed path of wealth and enjoyment", - so goes the prayer in the Upanișad of I'śa.

The life of the Vedic Aryan centred around the sacrificial fire. The $y a j \tilde{n} a$ was the ritual of life's struggle and fire was its sacred symbol.

The Aryan viś or tribe was a wandering herd. Freaks of nature like flood and drought, depredation of wild beasts and the search for game animals drove it from place to place. Fire and cattle gave a pause to its members' wandering and bound them to the earth. The forest was burnt and cleared to make a habitable terrain. The precarious dependence on the meat of game was mitigated with the secure supply of meat and milk from domesticated animals. The economy of hunting gave place to the superior economy of cattle-rearing. Hence the prayer that encircled the sacrificial fire was for prajā (people) and pasú (cattle). More men to fight and more animals for food, - these were the needs of time.

In those primitive conditions wealth and enjoyment could not be secured by individual talent. Whether for hunting or for animalkeeping, whether for safety or for settlement, the whole tribe had to work collectively. So distribution was also collective and equalitarian. "For acquiring wealth be of the same mind, same voice and same determination, be equal (samänamastu)", - so goes the behest in the Samjiñannasūkta of the Reveda. The tribe was the same in blood and under the same rules of discipline. It was not ruled by an individual or a class. The yajñ was a collective performance. Its goal was power and wealth, i.e., expansion of the tribe and production of food. Woman was at the forefront of these operations. She is the creator of life and the custodian of the mysteries of birth. The male has to offer his retas 
(the seed of procreation) in her yositagni (fire of the ovum) just like offering in a sacrificial fire to secure the multiplication of the kin. Thus she is the mother of the tribe. She roasts the meat of game and serves the food among the folk. Thus she is the keeper of the tribe. The palaeolithic tribe was matriarchal. There was no domination of woman by man.

The matriarchal society left its legacy in the mother principle, the primal energy of procreation (śakti) conceived as the cosmic mother. In the Rgveda and in the first canto of the Mahābhārta the early tribal fathers are known by their mothers' names, viz. Aditi, Diti, Danu, Kadru, Vinatā, Pulomā, etc. These original mothers were the source of all mankind. In the Rātri and Srì Süktas of the Rgveda the creative power of the universe is invoked as a goddess. How and when the mother was set aside by the leader of the herd and the patriarchal system replaced the matriarchal principle is a theme which belongs to the widest ranges of speculation.

The uni-caste society of the krta or satya age is the mythised version of the tribal herd bound by ties of kinship and tribal discipline. There was no country and no state. There was the folk, the viś,jäti or gana. Labour and property were common and everyone had his share in each. The Sanntiparva of the Mahäbhārata recalls this stateless society of old. "Then there was neither a state nor a king, no penal laws and no law-maker. The people protected one another out of their innate sense of duty (58.14)". "In ancient times the only retribution was censure. Then came rebuke, then fine. Now capital punishment has been introduced (273.19)". "By collective performance of duties they lived happily in ancient times. They had nothing to be adjudicated or expiated for (276. I I)". Man was free within the limits of tribal rules.

The first of these was allegiance to the herd. Murder of a kin was unforgivable offence. There was no rule in relation to people outside. An alien was a foe who must be killed and plundered. There was no compunction for the enemy tribe. A tribal war was a war of extermination. Defeated tribes were wiped out and the victors appropriated their cattle. Hence war and plundering became an industrial enterprise, a source of wealth like hunting and cattle-rearing.

In course of time, new methods of economic production were learnt. Hunting and cattle-rearing were followed by agriculture, crafts and trade, one after the other. Animal labour was substituted for human labour. The saving of labour led to a surplus of wealth. It was now possible to use and feed the men and women captured in tribal feuds. The animal was yoked to the plough and the captive alien was 
harnessed behind. Like animal, man also became a booty of plunder and an article of use. The fallen foe was not killed. He was taken in chains and put to productive enterprise. "The vanquished is the victor's slave, - such is the law of war", - so goes the maxim in the Mahābhārata (IV. 33. 59f.). Thus came slavery, the two-caste society, social laws and fusion of tribal blood.

Agriculture and the slave system simplified the problem of living. In the stone age, man had to live by collective application. Everyone was a hunter and fighter and everyone had to participate in the tribal enterprise symbolised in the yajña. Life became easier with the successive introduction of fire, animal, slave and iron. There was no further need of the hard collective work of the entire folk. The appearance of the slave, division of labour and differences in industrial skill slackened the ties of tribal solidarity. Skill and organising ability came to count and threw up men of influence beside the patriarchal head.

Changes like these swept upon the krta age and buried it into oblivion leaving not a trace of the original story. It was not a quiet peaceful age of piety and plenty as poetic fancy would have. Every hour of existence was earned with tear, sweat and blood. Still the small society was homogeneous and egalitarian and everyone shared the sorrows and the prize. It took thousands of years to decline and die. And long after that reminiscences of the old tribal collectivism survived in various forms.

The memoirists and chroniclers who accompanied Alexander when he penetrated into the Indus valley observed that the Mausikanas (Mūṣika) lived by hunting and had a common meal. They also noted that some tribes of the land of the five rivers used to plough the fields together and the members took a bagful of the harvest for the year (Strabo, XV.i.66). The old settlers of the planes who refused to bow down to the Aryan conquerors and were branded as Mleccha (barbarians) in consequence, maintained the old traditions of collective ownership and enterprise to a large extent. Their home was the hill and the forest, birds and animals were their companion and hunting and freebooting their profession. Birds and cattle, the flesh of game and the booty of plunder were their collective property which all could share and enjoy. The Kirātas, the Nișādas and such other aboriginals who appear in the Aryan narratives give a glimpse of the primitive egalitarian life.

The mixed society which evolved after the Aryan conquest and settlement gave a go-bye to tribal equality. But relics of old collectivism remained in different spheres. Outside the homestead and 
agricultural lands was the vast grazing ground which was the village common. Homestead lands and agricultural fields were owned by the kula or family and the family estate was impartible. Industrial enterprise was organised as cooperative guilds. Artisans specialised in one craft, lived in the same area, were bound by the same laws and obeyed a common leader. They plied their arts jointly and divided the income in proportion to work. In the villages there were such organised crafts of fishermen, carpenters, blacksmiths, etc. In the cities there were guilds of ivory-workers, florists, weavers, etc. Merchants venturing on hazardous maritime and caravan journey used to make a common pool and move in a team. They apportioned the risks of the journey along with the investment and profit.

The tribal element had the longest lease of life in the civic administration of the town and the village. The village had its assembly and public hall. The elders sat together, guided the deliberations and sometimes took the responsibility for collecting and sending the king's revenues. The villagers discharged their municipal duties together, e.g., making of roads, digging of wells, building of bridges and running the work of the central moot-hall. This hall, according to the Jataka stories of the Pali canon, was a house of assembly, a pavilion for games, and a shelter for travellers and for the stranded, all at the same breath (VI. 333). Education, irrigation, public works and social welfare were among the collective duties in which women took part as much as men. In the town also the same system was in vogue. The aldermen collected municipal rates and taxes, raised loans for civic works and were responsible to the townsfolk for the accounts and for their job (Jät. IV. 108 and Commentary).

In the organisation of agriculture and industry and in local civic administration of the South traces of collective enterprise were more clear and persisting. This was because the South preserved a larger element of the old non-Aryan life, protected as it was from the North by the natural barriers of the Vindhya range and the Dandaka forest. The Tamils of the far South bore indelible marks of community life in their land system and local administration which did not quite fade away even at the advent of British rule.

\section{STATE, CASTE AND PROPERTY}

At a certain stage, it is not known when and how, the patriarch assumed the crown and became the monarch. But the process of transition from the tribe to the state is not difficult to discern.

In the early phase of tribal disintegration families (kula) arose as discrete units within the tribe (vis). The master of the herd (vispati) 
was assisted by the heads of families (kulapati) who used to assemble in the folk moot called sabba and samiti. They deliberated over tribal problems like those of food and fighting and helped the chief in administering the customary rules. During the early Vedic age there was no rästra or territorial state. There were tribes like Jadus, Turvaśas, Pūrus, Anus, etc., who had no fixed territory. The heads of these tribes could rise to imperial hegemony by beating their rivals; but the hegemony would be over the tribe (vis), not over the country (räștra) (Taittiriya Saṃhitā, II.3.3-4). Meanwhile, as the wandering tribe had settled on land with agriculture, it had a fixed territory, a country. The master and the country together formed the foundation of the state. The different tribes settled down in different parts of the country and the idea of a territorial state began to appear (Aitareya Brāhmaṇa, VII.3.14). The vișpati or head of the tribe became bhippati, the master of land or the king. The people (vis or gana) came to be known by their country (ianapada or rajjya). The kulapatis were supplanted by amätyas, i.e., officers who were paid by and responsible to the king and who helped him run the administration. Among them were the high priest (purobita), the army commander (senappati) and the village headman (grämani). With the development of civil administration the chief officers came to constitute a council (parișad) to assist the king with their deliberation. The institution is mentioned in Kauțilya's Arthaśāstra, in Aśoka's inscriptions and in later literary and epigraphic records. The tribal set up of sabba, samiti, kulapati and viśpati was replaced by the civil system of parișad, amätya and bhīpati. The free communal institutions of sabba and samiti receded from the heart centre of the new polity and struck root in the village (gräma) and town (nigama) which were the local units of the expanding state.

The emergence of the state was accompanied by far-reaching changes in society and economy. In the economic sphere the rise of individual enterprise was a basic innovation. The ages of stone and copper witnessed a rather slow progress in some elementary industries like glazed pottery and textiles of cotton and wool. The invention of iron accelerated the development of industries and introduced a large variety of enterprise. Specialised crafts, in their turn, quickened the pace of exchange and trade. Division of labour and vocational skill became features of the new economy. The field of collective enterprise was reduced and was gradually invaded by individual enterprise.

Functional division had its counterpart in the caste division of society. The primitive viś was collective. Both production and consumption were common. It was of same blood, same colour, same vocation and under same rules. Now there were different strains of blood, variety 
of vocations and rule of the state. Different tribes, Aryan and nonAryan, lived together and commingled. The old viś became a legend; the tradition of uni-caste society gave way to the bi-caste society of deva (gods) and asura (demons) or the arya (Aryan master) and the dasa (non-Aryan slave). It was not the outcome of a split of the original vis but of its impact with the hostile aboriginals who were now admitted as slaves and wage-earners within the Aryan society. The masters and the slaves became the two castes or varnas (colours), the white-skinned and the black-skinned, as they have been labelled in the Rgveda (I.100.18, I.I30.8, IX.4I.I). The varnas were originally racial entities distinguished by the colour of their body, the Aryan vis being identified with the white masters and the non-Aryan tribes with the black slaves and hirelings. With the progress of individual enterprise, vocational division, saving of time and accumulation of a surplus of wealth the vis suffered disintegration. The main body, i.e., the Vaiśya remained fixed to productive pursuits, viz. agriculture, cattle-rearing and trade. The surplus wealth went towards the maintenance of two new castes or varnas, viz., the Brähmana and the Kșatriya, not distinguished by the colour of skin but by their professions. The Brāhmana performed sacrifices for securing social welfare, cultivated the philosophies and the sciences and formulated the laws for society on the basis of equity and custom. The Kșatriya was occupied with the defence of the realm and the running of the administration. The three varnas specialised in their respective jobs and each was assigned a place in the social hierarchy in accordance with the dignity of its service. Below the three was the fourth caste of Sūdra or Dāsa, no longer an alien tribe but absorbed as a subordinate partner within the Aryan system.

The new caste system, unlike the old, was not a division of race or colour. It was a division of work. As labour became more productive and wealth was saved the surplus was spent on the maintenance of the orders of religion and state. In the beginning, these vocations were not strictly hereditary. A Kșatriya could excel in philosophical knowledge and become a Brāhmana. A common story in Vedic literature is that of Viśwāmitra who was born a Kṣatriya but became a Brāhmaṇa by acquiring Brähmaṇical knowledge and virtues. The Satapatha Brähmaṇa gives a similar story about Janaka, king of Videha. A Brāhmaṇa might acquire a kingdom by dint of his valour and become a Kșatriya. $\mathrm{He}$ came to be known as Brahmakșatriya. In the Matsyapurāna the Brāhmaṇas descended from the sage Bhrgu are mentioned as founders of royal genealogies. The Vaiśya and the Sūdra could improve their status provided they had necessary virtues and talents. Conversely, by choice or by accident, one might be demoted from a higher to a 
lower caste. The Purānas and the Aitareya Brāhmaña show instances of these two categories. Later on, caste and vocation became rigidly fixed by heredity according to the laws of the Smrtis or Dharmaśatras. Social and economic divisions were identified and graded. The four orders labelled as Brāhmaṇa, Kṣatriya, Vaiśya and Sūdra were separated from and related to one another by a set of laws framed according to the Brāhmanical scheme of division and synthesis.

A necessary consequence of individual enterprise was the growth of private property. Whether for hunting or for animal-keeping, whether for cultivation or for industrial pursuit, collective labour was no longer necessary. Anyone could recover some wasteland by means of an axe and a spade, turn the soil with an iron ploughshare and a pair of bullocks and thus become owner of agricultural land. "The field belongs to him who removes the weeds as the deer to him who stalks it", - such is the injunction of Manu's Dharmaśastra (IX.44). In the sphere of industrial arts the old collective enterprise still prevailed, but the income was shared and not jointly owned. The trader made his fortunes by exchanging the products of agriculture and industry. Property which was formerly enjoyed by all in a commonwealth was now owned by some of its members.

In older days gold was an article of luxury and decoration. It was used to add beauty to the human body and its surroundings. Expansion of industries and the needs of exchange brought gold from the home to the market. At first gold ornaments, then fixed metallic weights became the common medium of exchange. The niska (an ornament), the satamana (a standard weight, literally a hundred-weight), and the suvarna (a gold coin) mark the three stages in the evolution of currency. In bar and coin, gold was piled up in the coffers of the rich. Money began to reproduce itself through investment and usury.

Engels wrote in the Anti-Duhring that in India the introduction of money economy led to the replacement of joint tillage of the soil by individual tillage. He adds further that "at a later stage it puts an end to the common ownership of the tillage area, which still manifests itself in periodical redistribution, by a final division; finally it forces the dividing up of whatever woodland and grazing land still remain owned in common". There is no evidence to show that joint ownership and tillage were destroyed by the monetary system. The common woodland and pasture survived at least two thousand years after the appearance of metallic currency. The natural process of evolution would rather suggest that as labour became more productive property was easy to acquire and came within the reach of the individual. Stone and fire could not break collective initiative; it broke under the stress 
of animal labour and slave labour. Iron hastened the disintegration. With stone implements collective effort was needed to till the soil. Now the soil was turned easily with the iron plough-share drawn by bullocks and driven by slaves. The owner of slaves, bullocks and the plough became the owner of land. Private property in land was established long before the introduction of gold currency. The satamäna and the kärșäpana only hastened the transfer of land by sale and the formation of big estates.

As caste and property became crystallised the state developed its features. The vispati and the kulapatis were sharers in the tribal commonwealth; the räjan and the amätyas were paid men. The state had to pay them for their service, at first in kind, later in cash. The king took a part of private income as revenue. As the state assured safety to property, the holder willingly gave a part of it to the state.

In the beginning the king's share was not fixed and regular because private property and income had not yet taken clear shape. The individual was not yet grown into a distinct entity within the society. Either the king made an occasional levy at his will or the individual made a voluntary contribution according to his capacity or needs of self-interest. This levy or contribution was termed bali or offering, something that is given by way of propitiating the gods or the kings. Gradually, the state extended its power, the size of the army and of the bureaucracy increased, private property was established and protected by the state. Then the rate of assessment also was fixed. The land revenue was no longer the casual bali but the regular bbäga (share), the king's share customarily fixed at one-sixth of income. The bali now became an additional and irregular assessment on agriculture. The sulka was an assessment of uncertain rate on industry and trade. Officers were appointed throughout the country to realise the șadbhäga (onesixth share) and the sulka and other taxes which were raised from time to time to meet the growing needs of administration. The contours of the state became clear and well-defined.

The story of thousands of years is hidden in the hymns of the Rgveda. Like the earth which contains within its layers the steppings of an ancient culture from age to age, the Vedic literature reflects, though dimly sometimes, the earliest phases of social transformation. The dreaming poet captured the faded memory of the casteless tribal commune adding a liberal dose of his idealistic fancy. The relentless conqueror infected with racial arrogance by the long and bitter tribal wars described the two-caste society of masters and slaves. As the fight ended in coexistence and fusion the social planner gave the blueprint of the new society on the basis of fourfold division and synthesis. 
The end of tribal collectivism is marked in the Purusasuikta of the Rgveda which gives a mythic story of the origin of the four castes and in the hymn of Apālā which testifies to the establishment of private property.

The emergence of the individual was not an unmitigated evil as later poets and idealists would seem to imagine. As the labour of living became easy and the rigorous discipline of the commune was slackened, the person had the time to turn inward into his mind and his soul. He acquired distinct mental and spiritual traits which went to form his individuality. The individual served society with his aptitudes and attainments. He also opposed society with his rights and desires. In Europe, the dualism of individual and society was sought to be solved by means of the state. From the days of Plato and Aristotle down to our own time the aim of political philosophy has been to strike a balance between the two and secure a workable adjustment of personal rights and general welfare. Indian savants also sought for a stable equilibrium through the mechanism of the state. The myth of mätsyanyaya (ethics of fishes) which is the corner-stone of Indian political thought, says that in days of yore when the people were afflicted with anarchy, the strong preying upon the weak as in the fish world, they approached the strongest man, offered him tribute (bali) and their obedience and obtained protection in return. Thus originated the king, the revenue system and the civil administration. The story was never seriously meant to be a historical account. It only emphasised the philosophy of state, the theory that the state exists upon an implicit contract between the people and the king and that it holds the scales even between the strong and the weak.

But the peculiarity of Indian thought is that it never regarded the state as the only, or even as the main forum of this compromise. It is not the king who assigns the place of the individual in society. The unit and the whole are related by their own organic laws. It is his innate nature, his quality (guna) and his deed (karma) which determine one's caste. Within the limits and opportunities of caste he grows his individuality. The cooperation and synthesis of castes ensure progress of society. This is the scheme of compromise and adjustment visualised by the sages and formulated in the Smrtis. Thus were laid down the rules of castes by social philosophers. The state or the king was merely the guardian of these rules (dharmasya goptā).

Thus the caste system was built up with a recognition of variations in human nature and as a plan to fit these variations into a hierarchical structure according to the needs of society. Given sufficient fluidity and flexibility, this was a nice scheme for solving the dichotomy of the 
individual and the community. In the beginning, this flexibility was maintained to some extent; one was not irrevocably attached to the caste within which he was born. But a perpetual and universal reshuffling on a right assessment of potentialities is a utopia and outside the limits of practicability. This was proved to the hilt towards the end of the Vedic period and the beginning of the Smrtis.

THE CASTE AND THE CLASS

The law-givers of the canon sought to give the caste system an inflexible rigidity. The codes of Gautama, Bodhāyana and Āpastamba followed by later canon fixed the varna to birth for life and introduced restrictive regulations on marriage, touch and table. That these laws were meant to be obeyed is shown in descriptive literature. The narratives of the Rāmāyaṇa and the Mahābhārata and of the Jātaka stories of the Pali canon further show that the three upper varnas not only remained in enjoyment of dignity and position, but many of them also rose to phenomenal wealth and power. The Brāhmaṇa was not necessarily a recluse who had left earthly attractions and retired to the forest in quest of truths. He was assigned revenues of villages or taxfree lands called brabmadeya by royal charter. Not all such beneficiaries were śrotriyas, devoted to Vedic studies or to the cause of religion and learning. There were many who preferred the Vaiśya occupations of agriculture, cattle-rearing, trade and usury and amassed fortunes conventionally stated in the hyperbolic figure of eighty crores of gold coins. In the Dighanikāya of the Pali canon figure Brāhmaṇa owners of thousands of acres of land which they cultivated by means of slaves and wagemen and who lived like princes on their toil (III.i.I, IV.i.I, XII.i.I). Even those who stuck to the rites and rituals proper to their caste came to be organised into vocational guilds like other crafts and professions. Manu and Nārada give the rules about division of their earnings (M.VIII.206,210, N.III.8). Stories of the Mahābhārata (XII.29.1 24f.) and of the Jatakas (I.343, III.45) represent them as bargaining for sacrificial fee and quarreling among themselves over their shares. Of course, all Brāhmanas were not secularised. But the fixation of castes to heredity and the unstinted flow of charity naturally led to deviation and corruption on quite an extensive scale.

Unlike the Brāhmaṇas the Kṣatriyas and the Vaiśyas do not appear in post-Buddhist periods with the precision of a well-defined caste determined by heredity. State-craft and military vocation were not confined to one blood group. There is no lack of Brāhmaṇa, Vaiśya and Südra royal dynasties in the annals of India. The Sătavāhanas were Brāhmanas, the Guptas were Vaiśyas and the Nandas were known to have been Südras. Kings of foreign races like Yavana, Saka, Kus- 
hana and Pahlava were not labelled as Kșatriyas. According to theory, the Kșatriyas were the order devoted to war and civil administration and gifted with necessary virtues. In the epics and legends all the ruling families of Aryan states are classed within this order. In later historical records, however, only the ruling families of the Gangetic oligarchies appear with the label of Kșatriya.

The Vaiśyas were the most numerous caste and the main body of the vis. They show none of the traits of a social or economic class. Some of them climbed up to the highest rung of the economic ladder. The merchant sent his cargo across the sea as far as Mesopotamia and the East Indies and became master of the conventional eighty crores. The village lord enjoying revenues of villages by royal charter and the landowner working his vast estates by means of gangs of slaves and wagemen belonged to the same fortunate fraternity. But the Vaiśyas were not limited to these wealthy few. There were small peasants, artisans, hawkers and petty officials who formed the main bulk of the varna and who had no class identity with the commercial and agricultural magnates at the top.

The Sūdras had a perceptible class character. They were mainly slaves and men working for hire or wages. The slave had no persona. He was his master's chattel like animals. He could not own property. His labour, rest and feeding depended upon the master's will. The slave system originated from war. Men and women of the defeated tribe were reduced to slavery. Their number was swelled by the children of slave mothers and by others who suffered the reverses of fate. The slave was bought and sold in the market. Sometimes he was a medium of exchange like coins. The wage-earner was a free man and nobody's property. But in social position he was no better. Without capital, skill and combination he was at the mercy of the employer and had to work under his terms. While slavery originated from the right of the strong over the weak, the origin of the wage system was destitution and poverty.

The slave and the wage-earner had to work in the household or in the farm or workshop of the master. They were in close contact with him. As servants of the upper orders they were an integral part of the Aryan society.

The degraded races called the Mlecchas were below the Sūdras and outside the caste system and the pale of Aryan society. Many of them went far away into the forests with their vocations of hunting and freebooting. Others settled down very near. Their vocations were unclean but, nevertheless, indispensable to the civilised community, e.g., sweeping, corpse-burning, public executioning, etc. Hence they 
lived outside, but not very far from the Aryan town and village. They had a society of their own, a society of outcastes, despised and despoiled of property.

In course of time the four castes ramified and were interwoven into a countless number of sub-castes and mixed castes. Inter-caste marriage in defiance of canonical laws went side by side with the rise of new crafts and vocations. The progeny of mixed marriage was given a new caste name and a new profession. The legists threatened the transgressors with severe execrations but could not help accepting them and their children. Kautilya even recognised amorous union, purchase, abduction and rape (gändharva, äsura, räkșasa, paiśäa) as legal forms of wedlock although with a stigma attached to them. The result was further ramification of the caste system. As one passes from the earlier to the later Smṛtis through Manu, Viṣnu, Vṛhaspati, Yãjñavalkya and Nārada, castes mix and multiply through the conflict and synthesis of the tightening Sāstra rules and loose popular practice.

The laxity in marriage and intercourse among castes was promoted by two factors, viz., the influx of foreigners and the rise of urban civilisation. Yavanas, Pahlavas, Sakas, Kushanas, Chinas and Hunas came successively and settled in the country. Some founded states and royal dynasties, some came for trade. They adopted Indian religion and culture and entered into matrimonial relation with Indians. The aliens, big and small, who made India their homeland were naturalised. The Sătavāhana king Gautamiputra Saatakarṇi who claimed to be a blue blooded Brāhmana married his son to the daughter of the Saka king Rudradāman. The Ikșaku kings who were Brāhmaṇas had similar marital relations with the Saka kings of Ujjaini. The examples set by royal families were obviously followed by the commoners. The cities which were the meeting ground of different races, castes and cultures dissolved social barriers and prejudices and nursed the growth of a mixed race with a liberal culture. But as the mixing and fusion grew apace the Smrtis forged new rules to enmesh the new-comers within the folds of the Aryan system.

It is an intriguing question whether this caste system, continually changing and ramifying, was the determining factor of society and superseded the force of wealth. Or is it that the three upper castes represented the class of property and privilege while the rest were the destitute proletariat? Are the varnas mere classes in the system of production under the gloss of priestly idealism?

Dr. B. N. Datta ${ }^{1}$ holds this view and believes that the varna is an

1 Studies in Indian Social Polity. 
economic class. The view is not supported by available data on ancient society. To a certain extent the varna was infected by class characteristics. But economic changes did not overcome caste differences and free the individual from the dispensations of his birth and blood.

"Wealth (artha) is the chief. Duties (dharma) and desires (kama) have their roots in wealth", - so says Kautilya, the author of the famous book on polity and economy (I.7). The individual was never free from the overwhelming power of wealth and property. Social position was never totally dependent upon the caste to which one was born. The Brāhmana who had to live by agriculture, craftsmanship or hunting had no honour and position. The prince who lost his throne and was reduced to begging or slavery could not rest on his pride. The merchant whose caravan was looted by brigands or whose cargo suffered shipwreck in the sea was humbled to the level of Südras. In the Majjhimanikāya of the Pali canon a sage cynically remarks that a man of inferior caste, if he has riches, can keep one of superior caste to serve him as slave (84). In a Jātaka story another cynic contends, "Wise men and fools, men educated and uneducated, do service to the wealthy, although they be highborn and he be baseborn" (IV. $356 \mathrm{ff}$.). Against this challenge the wise Bodhisattva has to rely on the next world where the poor sage and the wealthy fool will fare according to their deserts. Wealth confers family dignity and poverty takes it away, - such is the frank confession in the Mahābhārata (III.192.21). That the dignity of the varna was spoiled by the association of a low calling was an old and recognised fact. Caste had its corresponding status only so long as it was attached to its appropriate calling.

There are instances that divisions of wealth prevail over divisions of of caste. But the two divisions hardly concur and coincide. In the pyramid of wealth and economy the successive layers are; (a) despised and segregated labour, (b) labour without right and property, - the dāsa and the bbrtaka (wage earner), (c) small freeholders, artisans and officials, (d) high officials, merchants, bankers and landowners. The first and the second, corresponding with the Mleccha and the Südra, fit in with the caste hierarchy, not the third and the fourth. Those Brāhmanas and Kșatriyas who remained true to their professions and virtues were outside the conventional categories of want and abundance and commanded the esteem and influence proper to their castes.

On the contrary, there is no dearth of cases where the caste overlaps the class. If the rules of the Dharmaśāstras and of the Arthaśāstra are read together it will appear that the two divisions were understood as quite distinct. According to Manu, a Südra is not free from bondage even if he is released, for who can liberate one whose essence is 
slavery (VIII. 4-14)? Among his work prescribed in Nãrada's Dharmaśāstra are dirty jobs like removal of human excreta, picking up leavings of food, massaging the naked body, etc. None of the codes concede the slave the right of property. But it is strange that the injunctions in Kauțilya's Arthaśāstra in the chapter on slavery are quite different and opposite. The slave is protected from the unclean services specified in Nãrada. He is given the right of property and inheritance. After his death his kinsmen have priority of claim over his master on his property. Right is lost over a violated female slave who must be set free.

The paradox is resolved by two observations in Manu and Kautilya. According to Manu, a Sūdra cannot get out of bondage even if he is released. According to Kauțilya an Ârya does not lose his birthright even if he is enslaved. The hard rules of Manu and other Dharmasaastras are meant for the slaves of Südra caste and not for the slaves of the superior castes whose number was few. The soft rules of Kauțilya's Arthasaāstra in the Dāsakalpa chapter are applicable to the Ārya slaves only. Cursory references of Kautilya to slaves outside this chapter, obviously meant for Südras, do not show the same enlightened and humanitarian attitude. Here the slave and the wageman are classed with hogs and cattle and the master has sexual rights over the slave woman (II.25).

Evidently, slavery cut across the boundaries of caste but could not efface the boundaries. When an Ārya was reduced to bondage a price was fixed upon him. He would be redeemed on payment of the price to the master. Popular stories confirm the words of law. In the Vessantara Jātaka a prince who gives his daughter to slavery puts a high price on her lest a lowborn should pay it and break her birthright. Poverty and degradation did not completely eclipse the pedigree of an Arya. Slaves did not attain to a perfect class formation in ancient India as their counterparts did in ancient Egypt and Greece. There were slaves without rights and slaves with rights and privileges.

Much less were the three upper varnas identified with the classes of wealth and property. The latter consisted of great merchants, landowners and village lords. They were mainly Vaiśyas, a few Brāhmaṇas and Kșatriyas. Property and privilege were separate. Privilege went with social precedence to the regular Brāhmana while the secular Vaiśyas were gradually reduced to the level of Súdras by law and practice.

Recently Soviet Indologists have started reexamining and rewriting Indian history in the light of Marxian historiography. They have 
periodised Indian history into the conventional phases of primitive communism, slavery, feudalism and capitalism. According to them class struggles appeared as the inevitable dialectical phenomena under the garb of varna and formed the central thread of social evolution. ${ }^{1}$ This is far from true. The castes never converged with the classes. Rather, it was the castes and numerous sub-castes along with their attendant vocations which prevented the bifurcation of society into two hostile classes. The Indian social polity never assumed the features of slave society or of feudal society. The slaves and wage-earners were not a very numerous class. Nor was their life as miserable as that of the slaves of ancient Egypt, Babylon, Greece and Rome. They were treated like animals. But the Sãstras enjoin that even animals are to be treated with kindness out of the master's own interests. Many did not live up to this enlightened standard. But such was the difference between Indian and Western standards that Megasthenes with his Greek eyes could not see any slavery in India. The worst sufferers of social injustice were the unclean Mlecchas who lived on the fringes of Aryan society.

Few traits of feudal relation are visible in the land system despite great inequalities in landed property. Large estates did not carry with them any legal privileges. Intermediary interests between the king and the tiller appeared with the practice of donating land and assigning village revenues by means of royal charter and also with the introduction of tenancy system in agricultural land. These practices did not create a class of privilege over the peasant freeholder. He had the agricultural (kșetra) and homestead (västu) lands as his patrimony. The grassland (vraja) and wasteland (kbila) were the village common. The village headman was originally a persona grata who participated in the coronation ceremony and was known as king-maker (räjakartā). At a later stage he was assigned the village revenues by royal charter and still later he became a salaried official. In the Jataka stories he appears frequently as an oppressive overlord but never in the role of a parasitic noble reducing the peasantry to serfdom. The peasantry lost none of their rights under a royal charter; they only gave the king's dues to another man. Bureaucratic despotism could not sap the spring of rural life which drew upon the tradition of tribal collectivism and manifested itself in the corporate discharge of public affairs. The industrial guild (śrenī) was a similar group with corporate autonomy in which kings and their officers could not normally interfere.

It was this middle class, the small freeholder and craftsman, the lower Vaiśya who formed numerically the largest class and who held

1 E.g., D. A. Suleykin: Basic questions of the Periodisation of Ancient Indian History. 
the balance between the high and the low, the rich and the poor. The thin line which differentiated the lower Vaissya from the free and skilled Sūdra gradually faded out. In Yãjnãvalkya's Dharmaśāstra Sūdras are allowed to pursue the Vaiśya callings of agriculture, crafts and trade. In course of time the Vaiśya lost his caste pedigree and was deprived of the privileges of Vedic studies and regeneration (upanayana). They were reduced to the rank of commoners.

\section{DIALECTICS OF SOCIETY}

The caste system was revised and extended from time to time to solve the differences and discords that were repeatedly rearing their head. But it could not maintain a stable equilibrium. There were conflicts and struggles but these were not class-centered. Stories of the Jātakas show that king's officers and beneficiaries sometimes sucked the blood of the people, and the people, rendered destitute by extortions of the tax-collector, sometimes left their hearth and home and fled to the forests. Oppressive kings fleeced their subjects with benevolence, forced labour and emergency taxes "crushing them like sugarcanes in a mill" (I.339, II.240), -for is not his name viśámattā, i.e., devourer of the people! Sometimes the oppressed people would make a hunger march to the king or to his agent to demand redress; or again, sometimes the peaceful masses would break into furious resentment to destroy despotic kings and their officers. The Brāhmanas and the Jātakas give instances where the people expel or even execute their princes together with highhanded officials. Kautilya (VI.I), Manu (VII.I II) and the Sukraniti (IV.7.838f.) warn the erring king against this grave retribution of tyranny. In the Anusaasanaparva of the Mahābhārata armed revolt against and the deposition of unprotecting sovereigns are definitely enjoined upon the subjects (6r.32f.). The Ceylonese chronicles state that the kings of Magadha from Ajātaśatru to Nāgadarśaka being all parricides, the people banished the dynasty and raised a high officer named Siśunãga to the throne. The theory of mätsyanyaya and social contract was not a dead letter and the people were not always models of non-violence and peace.

As between the ruler and the ruled, so among the varnas there were jealousy and conflict. The Kșatriyas did not passively submit to the superiority of the Brāhmañas. From the later Vedic age to the Buddhist the struggle between the two castes kept the Aryan society in a vortex of agitation. King Vena stopped the sacrificial rites of priests. Pururavā confiscated the accumulated gold of the Brāhmanas and Nahusa had his chariot pulled by one thousand sages. During the days of the Upanișads this quarrel was intensified over the issue of animal sacrifice. The old school supporting animal-killing in the yajnas had 
their citadel in the Kuru-Pañcala country, i.e., in the north-west; the heterodoxies opposing animal-sacrifice had their foothold in Kāsi, Kośala, Magadha and Videha, i.e., in the eastern Ganges valley. The heterodoxies were led by the Kșatriyas and hence the Brāhmanas of the East who had thus lowered themselves fell from grace. In the Satapatha Brāhmana the eastern countries are forbidden lands for the northern Brāhmanas who retained their purity by sticking to orthodoxy. This caste rivalry revealed its philosophical content when king Janaka of Videha summoned a convocation at his court where Yājñavalkya, a Brāhmana of the East, defeated in polemics his orthodox opponents from the North and established his thesis of brabmavidya or knowledge of the Absolute (brabman). And king Janaka received the lore from him to become a Brāhmana.

Glimpses of this epic rivalry are to be had in other legends. King Kàrtavirya stole a sacrificial cow from the priest Jamadagni. This infuriated his son Paraśurāma who exterminated the Kṣatriya community. At last, according to the Rāmāyana, he was humbled by the Kșatriya prince Rāma who met his challenge by mounting the sling on his bow. The opposition against Vedic rituals reached its culmination in Buddha and his heresy. Buddha was born in a Kșatriya clan. Against the Brāhmanical ceremonials he preached a simple human and ethical creed and turned his wheel of Dharma over the eastern countries which had been the cradle of nonconformist doctrines. The books of the Pali canon frequently assert the superiority of the Kșatriyas over the Brāhmanas. The big Vaiśyas supported the former. It was the warm patronage of millionaires like Anāthapiṇdika, the business magnate of Srāvasti, which helped Buddhism to spread. The traders (sresthin) appear as the main benefactors in the votive gifts of the stüpa (mound) of Sanchi. Jina, the other great preacher of heresy, also was born a Kșatriya and was backed by the Vaiśyas or the mercantile community. The economic factor of this caste struggle is the fact that the Vaiśyas were the tax-payers while the Brāhmanas were the beneficiaries of extravagant royal bounties. Buddhism and Jainism were nurtured by the jealousy and rivalry among the upper varnas.

The economic motive of the rich Vaiśyas and of the Brāhmanas did not, however, convert the caste rivalry into a class struggle. $\mathrm{Had}$ it been an economic struggle between the rich and the middle classes, the majority of the Brāhmanas and Kșatriyas would have combined with the lower Vaiśyas against the wealthy merchants and landowners. Such a combination never happened in the caste and class equations of society. Buddha and Jina preached homely virtues for the common 
man. Their doctrines, though backed by the big merchants, did not serve the interests of property. In the struggle of the castes, besides the influence of wealth, there were rivalry for social power, regional competition and above all, the war of ideals.

Still less did the dialectics of society assume the appearance of a class struggle between the haves and the have-nots. The Vaiśyas, far from being vested with privilege and honour, were degraded to the status of Sūdras in course of time. The slaves, hirelings and the unclean menials were the most exploited and degraded classes. But they had no class consciousness which is necessary in an economic struggle. Compared to the middle classes they were few in number and they were scattered and unorganised. It was constantly dinned into their ears that their salvation lay in serving their Aryan masters. An object lesson for rebels was the fate of Sambuka, the Sūdra king who forfeited heavenly bliss though killed by Rāma's hand, for the sacrilege he had committed by performing Vedic sacrifice.

The Brāhmaṇa-Kșatriya contest for power was more essentially a struggle of ideas than a clash of caste or other interests. From the symbolism of the epics and legends Rabindranath Tagore discovered this idealistic conflict which profoundly influenced the evolution of Indian social polity. ${ }^{1}$ On the one hand, there was conformity and conservation enforced by vigilant rules of discipline. On the other hand, there was the urge for freedom, innovation and creation. On the one hand, there were the eternal values; on the other hand, the values of the age. The Brāhmana represented the thesis, the Kșatriya the antithesis. The Brāhmana lived in the forest. Cattle were the main means of his livelihood, meditation and sacrificial performances were his occupation. He raised walls between castes and clans with formal laws. He was concerned with the preservation of fundamental ideals from the mutation of time. The Kșatriya lived in the settled locality and was concerned with the affairs of state. The state thrived upon agriculture and industry. Hence he had to identify himself with the flowing tide of life. He had to modify ideas and rules according to the needs of time. While the Brāhmana stood for the formalism of social barriers, the Kșatriya was for expansion and inclusion. ${ }^{2}$

Brabmavidya or supreme knowledge had its origin in the seclusion of the forest where the mind could be focussed on the spiritual depth of existence. The mystic lore brought in its train the religion of love based upon the unity of God and man. While Brahmā with his four

1 A Vision of India's History.

2 Before Tagore, Swami Vivekananda pointed out this difference in a letter dated 3.3. 1894 written from Chicago. 
faces representing the four Vedas was the divine symbol of placid and immutable truth, Viṣnu with his four hands was the incarnation of flowing benevolent activity. The Kșatriya humanised knowledge with emotion and against the Brāhmanical cult of ritualism, espoused the cause of love or Viṣnu.

The two epics represent, through symbolic stories, the long process of this ideological warfare, the two incarnations of Vișnu, viz., Krșna and Räma coming out victorious in the end. The Kuru war was not merely a family feud for political power fought among the Kșatriyas. It was a war of ideas, Krșna leading one side, the other side being generalled by Brāhmaṇas like Droṇa and Krpa. The non-Vedic doctrine of selfless action dedicated to a loving God, the gospel of the Geeta, had its classic exposition in the battlefield which Kṛṇna delivered and Arjuna received.

The story of the Rāmãyaṇa begins with the Kșatriya sage Viśwāmitra visiting the palace of Ayodhyā and bringing out the young princes Rāma and Lakșmana into the struggle and turmoil of life. Rāma killed the räkșasa (demon) who disturbed agricultural operations. He met Ahalyã (meaning unploughable) who was reduced to stone deserted by her Brāhmana husband and brought her back to life. This means that the rocky soil abandoned by a Brähmana bloomed with vegetation at the touch of the Kssatriya. Then he won the daughter of mother earth, maiden of the "furrow line" (Seeta) by breaking the bow of god Siva and humbled the Brāhmaṇa Paraśurāma who was the scourge of the Kșatriyas. Thus was the youthful deliverer allied with the sageking Janaka, the foster father of Seeta, who was an ideal Kșatriya combining in himself the knowledge of brabmavidya, popular government and the pursuit of agriculture. Later on, Rāma is shown as the friend of the barbarian kings Guha and Sugriva. As Krṣna was the chum of the shepherds, Râma became one with the aboriginal tribes whose totems were the monkey and the bear. In a later age, the revengeful Brāhmana sought to defile his name by interpolating the fiction of Śambuka in the corpus of the Rāmāyaṇa and portraying him as a Brāhmanical agent for inquisitorial persecution.

Thus the Brāhmana sought to save the ancient wisdom from the onslought of time; the Kșatriya sought to revise it by incorporating new elements gleaned from life. These were the natural functions of the body politic which, under the semblance of opposition, cooperated to maintain the dynamic flow of progress. The last phase of this struggle is represented by Buddha the third human incarnation of Viṣnu, the God of the Kșatriyas. Buddha preached a human religion against Brāhmanical ritualism, denied the caste barriers in his samgha (monastic 
order) and spoke for the people in their own language, i.e., the Pali. During this long struggle ending in the Buddhist revolution, the Kșatriyas lost their identity and merged themselves among the rest of the people. Hence the Kșatriya is rarely heard of in the royal lines of the succeeding age. The Brăhmaña who resisted syncretisation and remained exclusive was able to keep himself intact.

\section{DECADENCE}

The flood of Buddhism swept out the protecting walls and unleashed the aboriginal diversities which reared their head. Before the flood subsided waves of foreign invasion inundated the soil and covered it with mushrooms of alien culture. The organic coherence of the Aryan community was lost. A supreme effort was needed for recovery and restoration of the communal soul.

The Brāhmana addressed himself to this task. The Vedas were compiled and made a rallying point for the distracted race. The scattered myths and legends, ideas and faiths lingering in racial memory were pieced together in a literary image which became a symbol of the great motherland (Mahābhārata) with her cherished ideals and values. And as the mixed races and beliefs began to spread with irrepressible virility, wall after wall were put to resist them by means of the laws of the Smrtis. The moving vehicle of Aryan lore became static and immobile.

Outside the groupings of caste and class, there were other groups which, with their corporate and autonomous enterprise, had kept a robust vitality in social life. Such were the religious orders (samgha), the industrial guilds (śren $\bar{\imath}$ ) and the political oligarchies (gana). As stagnation and corruption overtook the Brāhmanical society, these too were caught by the same disease. The increasing flow of royal and public bounties spoiled the ascetic purity of the monks. They kept slaves and servants who begged alms on their behalf (Jāt. III.49). Female slaves and dancing girls appeared in the Brāhmanical and Jaina temples to serve or perform for the gods and their mortal agents. They are represented in the Buddhist monuments as exhibiting their art at festivals. For many, monastic life became a comfortable career (Mahāvagga, I.49, Jāt. I.3 I I,340). The whole set of disciplinary rules laid down by Buddha in the books of the Vinayapitaka of the canon reveal a desperate attempt to stamp out luxury and corruption and to stop the rush of selfseekers and criminals in the samgha.

The craftsmen's guilds were originally free associations of producers who shared the dues and dividends of a joint stock. They were homo- 
geneous units knit together by the sacred ties of manual labour. In course of time, many of them grew into monopolies and became a threat to civil power. The wealth of the guild concentrated into the hands of a few bankers and merchants (sresthin). The working partners became idlers and employed slaves and hirelings to work for them. There was palpable distaste for manual labour and a desire to dabble in music, literature and religion and to go with the fashions of time. The Mandasore inscription of the Gupta period speaks of a silkweavers' guild whose members had taken to all kinds of cultural pursuits like music, astrology, religious discourse, story-telling, etc. The mutualism of the śreni gave way to individualism.

Meanwhile, the womenfolk of the upper orders began to descend rapidly in social esteem. Their degradation was foredoomed with the mass enslavement and prostitution of the females of defeated tribes. These unfortunate victims of racial pride ultimately spoiled the sanctity of the home. Even then, during the Vedic age, there were women like Gārgi and Maitreyi who could specialise in philosophy and aspire after brabmavidyā, Ghoṣā and Viśwavarā who could compose superb hymns and Apālā who could own property. The Buddhist movement brought to the fore holy nuns (theri) who earned prominent place in the scriptures. Then came the age of the Smrtis. Women were deprived of Vedic studies and the right of property. Manu regards them as tools for procreation. Like slaves they are to be subordinate to men at every stage of life. They should be faithful to the husband even though he be a lecherous rake, and to his memory after death. The widow had to live in penance and austerity. While the chaste housewife lived a colourless life at home, the wily courtesan became the centre of romance and allure.

All these symptoms of stagnation and decadence became prominent by the age of the glorious Guptas, another "golden age" of Indian history. A great empire unifying the Āryāvarta, foreign trade stretching from Rome to China, the epoch-making astronomical researches of Āryabhatța and Varāhamihira, the immortal verses of Kālidāsa, the lithe paintings of Ajanta and Ellora, the flood tide of the cult of devotional love (bhakti), - all these have given a unique lustre to the Gupta age. But this was the last flicker of a dying flame. After the imperial Guptas the stagnant and moribund society began to petrify. While the Empire was shaken by the successive inroads of the Huns, society was fragmented into innumerable castes and sub-castes, the Vedic religion lost its sap in a medley of mechanical rituals, the Buddhist order was seized with corruption and was split into multiple sects, the craft guilds and the tribal oligarchies lost their corporate 
freedom and became subservient to the dominant individual. In the cities gay Lotharios disported with glamorous nymphs (ganikã) while the women of the home, along with the producing classes were going down in social position. The Südra and the Mleccha remained sulking in passive discontent, indifferent to the shifting fortunes of their masters. There was fissure on the surface and smouldering heat beneath.

The brabmavidya of the Vedic Aryans was not a philosophy of abstract speculation isolated from life. Matter (anna), life (präna), mind (manas), knowledge (iñana) and bliss (änanda) are successive phases in the unfoldment of the Absolute Brahman. One must pass through the lower phases of attainment before aspiring after the higher. The body has to be energised by mastery of nature, the vital power and the mental faculty must be developed through proper exercise and self-discipline before one qualifies himself for the supreme knowledge and bliss. Only the one with health, energy and longevity is fit for the quest of the Spirit. This was not a philosophy of negation or renunciation. During the days of the Upanișads, kings like Janaka and sages like Yãjñavalkya preached and lived this philosophy.

But now, after the lapse of over a thousand years, this philosophy had gone through a complete metamorphosis. Brabmavidya was attenuated into six systems of speculative philosophy. It was pitched at the apex of every system on a maze of logic and words without the sap of life. Songs of philosophy were no longer concerted with the music of the agricultural and pastoral fields. Knowledge was separated from labour and philosophy became dry and lifeless. The fall of philosophy from the pragmatic base synchronised with the general onset of decadence. Dharma or the social code losing its vital elasticity became a mechanical chain eternal and immutable (sanätana). As life was ebbing out of the body, it accumulated germs of disease and the tissues began to rot.

When darkness was thickening all around, the best minds were busy tightening the chain or remained under the soporific spells of religion, philosophy, literature and art. It was not the incisive polemics of Samkarācārya or the catholic teaching imparted at Nālanda or the devotional lyrics of Jayadeva which could save the old heritage and stem the tide of a flood such as was never faced in the past. More than a millennium had passed since India had lost the strength that could match the vigour of Islam. 


\section{GLOSSARY OF SANSKRIT WORDS}

\begin{tabular}{|c|c|}
\hline Amātya & Officer. \\
\hline Bali & $\begin{array}{l}\text { Literally, offering to God or to the king; technically, } \\
\text { additional land revenue. }\end{array}$ \\
\hline Bhāga & $\begin{array}{l}\text { Literally, share or grain share; technically, regular } \\
\text { land revenue. }\end{array}$ \\
\hline Bhṛtaka & Wage-earner. \\
\hline Bhüpati & Master of the land, i.e., king. \\
\hline Brahmadeya & Land donated to Brāhmanas free of taxes. \\
\hline Brahman & The Absolute or supreme truth. \\
\hline Brahmavidyā & Philosophy of the Absolute. \\
\hline Dāsa & Slave. \\
\hline Dharma & $\begin{array}{l}\text { Duties imposed by social conventions and prescribed } \\
\text { in lawbooks. }\end{array}$ \\
\hline Gaṇa & People, tribal oligarchy. \\
\hline Gaṇikā & Courtesan. \\
\hline Gāyatrī & Cult of Sun in the Upanișads. \\
\hline Janapada & Country. \\
\hline Kārṣāpaṇa & Standard coin from about 6th Century B.C. \\
\hline Kṛta age & An age of perfection. \\
\hline Kula & Family. \\
\hline Kulapati & Pater familias. \\
\hline Mātsyanyāya & Literally, fish ethics, i.e., primitive anarchy. \\
\hline Pañchāgni & Cult of Fire in the Upanisads. \\
\hline Parișad & Advisory and Executive Council of officers. \\
\hline Rājan & King. \\
\hline Rāșțra & State. \\
\hline Sabhā & General Assembly of the village. \\
\hline Samgha & Religious order. \\
\hline Samiti & Village Council of elders. \\
\hline Satamāna & Formerly a weight standard, later a coin. \\
\hline Satyayuga & An age of perfection. \\
\hline Sreṇi & Craft guild. \\
\hline Sreșthin & Guild-master, merchant or banker. \\
\hline Srotriya & Brāhmaṇa devoted to Vedic studies. \\
\hline Sulka & Toll or customs dues. \\
\hline Suvarṇa & Literally, gold; technically, a gold coin. \\
\hline Varna & Literally colour; technically, caste. \\
\hline Viś & Tribe. \\
\hline Viśpati & Head of a tribe. \\
\hline Yajña & Sacrificial \\
\hline
\end{tabular}


I. Vedic literature (ca I $200-600$ B.C.). It is divided into four parts:

I. The hymns compiled in four books, viz., Rgveda which is the oldest, Sãmaveda, Yajurveda and Atharvaveda.

2. The four Brāhmanas in prose each attached to a Veda prescribing rituals of sacrifice.

3. The four Āranyakas associated with the four Brāhmanas giving rules for hermits dwelling in the forests.

4. The Upanișads drawn from the Āranyakas with additions, dealing with Brahmavidyā or philosophy of the Absolute.

II. Pali Canon (ca 600 B.C. - 200 A.D.) or Tripitaka. These are the sacred books of the Buddhists consisting of three sections:

I. Vinayapitaka laying down rules of monastic discipline, including, among others, the book Mahāvagga.

2. Suttapitaka laying down the code of conduct including among other books, the Dighanikāya, the Majjhimanikāya and the voluminous Jātakas or stories of Buddha's previous birth.

3. Abhidhammapitaka dealing with the philosophy of Dhamma.

III. The Mahābhārata (ca 600 B.C. - 400 A.D.) and the Rāmāyaṇa (ca 400 B.C. - 200 A.D.). These two epics incorporate along with the main themes numerous stories as well as social ideals and values.

IV. Smṛtis or Dharmaśāstras. These are codes of law or duty attributed to Gautama, Bodhāyana, Āpastamba (ca 600-200 B.C.), Manu, Viṣnu (ca 200 B.C. - 200 A.D.), Bṛhaspati, Yājñavalkya, Nārada (ca 200 - 700 A.D.), etc.

V. Arthaśāstra of Kauțilya (ca 300 B.C.). This is an outstanding work on politics and economics.

VI. Sukranitisāra (ca 700 A.D.). This is another work on the same subject.

VII. Purānas. There are eighteen books of this category one being the Matsyapurāna. They belong to different dates around the Christian era and contain genealogies of ancient kings along with geographical data and a mass of hearsay.

VIII. Greek writers. Historians who accompanied Alexander during his Indian campaign wrote memoirs. Megasthenes, ambassador of Seleukos to the court of Pātaliputra towards the close of the fourth century B.C. wrote an account of India. Later writers like Strabo, Diodorus, Arrian, etc. made use of these older materials now entirely lost. 